\title{
Adjuvant immunotherapy of dendritic cells and cytokine-induced killer cells is safe and enhances chemotherapy efficacy for multiple myeloma in China: a meta-analysis of clinical trials
}

\author{
This article was published in the following Dove Press journal: \\ Drug Design, Development and Therapy \\ 15 November 2017 \\ Number of times this article has been viewed
}

\author{
Yan Wang' \\ Benji Lv² \\ $\mathrm{Ke} \mathrm{Li}^{3}$ \\ Anqi Zhang ${ }^{3}$ \\ Hong Liu ${ }^{3}$ \\ 'Department of Clinical Laboratory, \\ ${ }^{2}$ Department of Blood Transfusion, \\ ${ }^{3}$ Department of Central Laboratory, \\ Liaocheng People's Hospital, \\ Liaocheng Clinical School of Taishan \\ Medical University, Liaocheng, \\ Shandong Province, China
}

Objective: The aim of this study was to systematically evaluate the efficacy and safety of the combination of dendritic cells and cytokine-induced killer cells (DC-CIK) adjuvant immunotherapy and chemotherapy in the treatment of multiple myeloma (MM).

Methods: Clinical trials were gathered by searching Web of Science, PubMed, Embase, Cochrane Library, Wanfang, and CNKI database. Outcome measurements including therapeutic efficacy, prognosis, immune function, and adverse events were extracted and evaluated.

Results: A total of 12 trials including $594 \mathrm{MM}$ patients were involved in this study for statistical analysis. Results indicated that compared to chemotherapy alone, the combination of DC-CIK immunotherapy with chemotherapy significantly improved patients' overall response rate (ORR, odds ratio $[\mathrm{OR}]=2.77,95 \%$ confidence interval $[\mathrm{CI}]=1.88-4.10, P<0.00001)$, disease control rate $(\mathrm{DCR}, \mathrm{OR}=2.90, \mathrm{CI}=1.72-4.90, P<0.0001)$, and life quality $(P<0.00001)$. The combined therapy showed advantages over chemotherapy alone in prognostic indicators including percentage of tumor cells $(P=0.04)$, serum levels of $\beta 2$-microglobin $(P<0.0001)$, M protein $(P<0.00001)$, and creatinine $(P<0.0001)$, and $24 \mathrm{~h}$ urine light chains $(P<0.00001)$. After combined treatment, $\mathrm{CD} 4^{+}$lymphocyte subsets' percentages, $\mathrm{CD} 4^{+} / \mathrm{CD} 8^{+}$ratio, and cytokines levels of AgNOR, IFN- $\gamma$, IL-2, and IL-12 were significantly increased $(P<0.05)$, whereas CD8 and $\mathrm{CD} 4{ }^{+} \mathrm{CD} 25^{+}$percentages and IL-4, IL-6, IL-10, and TGF- $\beta$ levels were obviously decreased $(P<0.01)$, indicating a recovered immune condition.

Conclusion: Adjuvant DC-CIK immunotherapy enhances the efficacy of chemotherapy for $\mathrm{MM}$ and improves prognosis probably by reconstructing immune function.

Keywords: cytokine-induced killer cells, dendritic cells, multiple myeloma, adjuvant immunotherapy, meta-analysis

\section{Introduction}

Multiple myeloma (MM) is the second most common hematological malignancy. ${ }^{1}$ It is characterized by aberrant bone marrow plasma cells proliferation, accompanied with excessive monoclonal protein production, which eventually causes hypercalcemia, renal failure, anemia, or lytic bone lesions. ${ }^{2}$ The incidence of MM has been increased in the past years, and it accounts for $\sim 1.8 \%$ of all cancers and $15 \%$ of all hematological malignancies, with an annual incidence of 6.5 per 100,000 people in western countries. ${ }^{1,3}$ Chemotherapy is one of the standard treatment regimens for MM, and the common chemotherapeutic drugs include thalidomide, velcade (bortezomib), lenalidomide, and other traditional drugs such as vincristine and cytoxan. ${ }^{4,5}$ These
Correspondence: Hong Liu; Anqi Zhang Department of Central Laboratory, Liaocheng People's Hospital, Liaocheng Clinical School of Taishan Medical University, Dongchang West Road, No 67, Liaocheng 252000, Shandong Province, China

Tel +86 I30 3453 4783;

+86 I5806358395

Email liuh4783@126.com;

zhang_angelalII9@I63.com 
Table I Information of DC-CIK immunotherapy

\begin{tabular}{|c|c|c|c|c|}
\hline Included studies & Therapeutic regimen & Administration route & Culture conditions & Cell dose (cycles) \\
\hline Ding $(2013)^{14}$ & CT (VD), CIK & Intravenous infusion & IFN- $\gamma$, IL-I $\alpha$, IL-2, CD3 & $>1 \times 10^{10}(\mathrm{ND})$ \\
\hline Gao $(2015)^{15}$ & CT (VDP/DEV/DCEV), DC-CIK & Intravenous infusion & ND & $2.5-5 \times 10^{9}$ (>3 cycles $)$ \\
\hline Lu $(2015)^{16}$ & $\mathrm{CT}$ (VCD), DC-CIK & Intravenous infusion & IFN- $\gamma$, IL-I $\alpha$, IL-2, CD3, GM-CSF, IL-4 & $1.2-2.4 \times 10^{10}(\geqq 2$ cycles $)$ \\
\hline Sun $(2012)^{17}$ & CT (Thd), DC-CIK & Intravenous infusion & IFN- $\gamma$, IL-I $\alpha$, IL-2, CD3, GM-CSF, IL-4 & $1 \times 10^{9-10}(2$ cycles $)$ \\
\hline $\operatorname{Tan}(2016)^{18}$ & CT (DEV), CIK & Intravenous infusion & IFN- $\gamma$, IL-12, CD3 & ND (3 cycles) \\
\hline Wang $(2015)^{19}$ & CT (VD/VDT/VCD/MVP), DC-CIK & Intravenous infusion & IFN- $\gamma$, IL-I $\alpha$, IL-I2, CD3, GM-CSF, IL-4 & $1.5-3 \times 10^{10}(>3$ cycles $)$ \\
\hline Yan $(2014)^{20}$ & CT (DEV/PM/DCEV/VDP), DC-CIK & Intravenous infusion & ND & $2-5 \times 10^{9}(>3$ cycles $)$ \\
\hline Ye $(2016)^{21}$ & CT (ND), DC-CIK & Intravenous infusion & ND & ND \\
\hline $\mathrm{Yu}(2016)^{22}$ & CT (VD), DC-CIK & Intravenous infusion & ND & $1.2-3 \times 10^{10}(\geq 3$ cycles $)$ \\
\hline Zhao $(2015)^{23}$ & CT (VD), DC-CIK & Intravenous infusion & IFN- $\gamma$, IL-I $\alpha$, IL-I2, CD3, GM-CSF, IL-4 & $1.2-3 \times 10^{10}(>3$ cycles $)$ \\
\hline Zhao $(2016)^{24}$ & CT (VD), DC-CIK & Intravenous infusion & IFN- $\gamma$, IL-I $\alpha$, IL-I2, CD3, GM-CSF, IL-4 & $1.2-3 \times 10^{10}(>3$ cycles $)$ \\
\hline Zhong $(2012)^{25}$ & $\begin{array}{l}\mathrm{CT} \text { (MP/DEV/DCEV/VEDM/ } \\
\text { VD/VED), DC-CIK }\end{array}$ & Intravenous infusion & IFN- $\gamma$, IL-I $\alpha$, IL-I2, CD3, GM-CSF, IL-4 & $1.5-3 \times 10^{10}(>3$ cycles $)$ \\
\hline
\end{tabular}

Abbreviations: CIK, cytokine-induced killer cells; CT, chemotherapy; DC-CIK, dendritic cells and CIK; DCEV, dexamethasone + cytoxan + epirubicin + vindesine; DEV, dexamethasone + epirubicin + vindesine; MP, melphalan + prednisone; MVP, melphalan + velcade + prednisone; ND, nondetermined; Thd, thalidomide; VCD, velcade + cytoxan + dexamethasone; VD, velcade + dexamethasone; VDP, velcade + dexamethasone + pirarubicin; VDT, velcade + dexamethasone + thalidomide; VED, velcade + epirubicin + dexamethasone; VEDM, vincristine + epirubicin + dexamethasone + melphalan.

medications were either singly used or more often used as combinations for newly diagnosed or relapsed/refractory $\mathrm{MM}$, and their usage usually varies across different countries depending on their availability (Table 1). ${ }^{4-7}$ Although chemotherapy usually relieves the gravity and improves survival, most patients eventually relapse and develop resistance to treatment, which were not able to completely eradicate small lesions and metastatic tumor cells. ${ }^{2}$

Adoptive cellular immunotherapy has been clinically used alongside chemotherapy for MM. It is achieved upon in vitro expansion of autologous immune effector cells and transfusion back to patients. ${ }^{8}$ Many studies have reported that adoptive immunotherapy can increase the efficacy of chemotherapy for various malignant tumors by reconstructing patients' immune function..$^{9,10}$ Dendritic cells and cytokineinduced killer cells (DC-CIK)-based adoptive immunotherapy have been widely applied to treat various malignancies. ${ }^{11}$ Dendritic cells (DC) are the most potent antigen-presenting cells. Cytokine-induced killer cells (CIK) compose a heterogeneous subset of $\mathrm{T}$ lymphocytes presenting phenotypes of both $\mathrm{T}$ cells and natural killer $(\mathrm{NK})$ cells $\left(\mathrm{CD}^{+} \mathrm{CD} 56^{+}\right)$and can be induced by IFN- $\gamma$, anti-CD3 monoclonal antibodies, and IL-2 in vitro. ${ }^{8,11}$ Studies have shown that co-culture with DC enhanced the cytotoxicity of CIK indicated by increased proportion of $\mathrm{CD}^{+}{ }^{+} \mathrm{CD} 56^{+}$cells and improved levels of cytokines such as IFN- $\gamma$ and IL-2. ${ }^{12,13}$ Compared to other immune cells such as cytotoxic T lymphocytes, NK cells, and tumor-infiltrating lymphocytes, DC-CIK have higher proliferative capability, broader anti-tumor spectrum, and stronger antitumor ability. ${ }^{12}$
In several clinic trials, DC-CIK immunotherapy combined with chemotherapy exhibited more prominent therapeutic effects for MM compared to chemotherapy alone, ${ }^{14-25}$ but systematic analysis assessing the therapeutic efficacy of this combined therapeutic strategy remains scant for now. In this study, we conducted a meta-analysis to investigate the treatment effects and safety of adjuvant DC-CIK immunotherapy combined with chemotherapy in comparison with chemotherapy alone for MM in order to provide scientific reference for the design of future clinical trials.

\section{Methods}

\section{Search strategy and selection criteria}

Literature was searched across Web of Science, PubMed, EMBASE, Cochrane Library, Wanfang, and CNKI database, with key terms "dendritic cells", "cytokine-induced killer cells" combined with "multiple myeloma". No language limits were applied. The initial search was performed in October 2016 and updated in March 2017.

Studies concerning MM patients were involved in our analysis. Patients in the experimental group received adjuvant DC-CIK immunotherapy combined with chemotherapy, and patients in the control group were treated by chemotherapy alone.

\section{Data extraction and quality assessment}

Data were extracted by two investigators independently (YW and BL); disagreements were resolved upon discussing with the third researcher (AZ). All involved studies were summarized as follows: first author's names, years of 
publication, study locations, tumor stages, number of cases, patient ages, therapeutic regimens, administration route, in vitro cell culture conditions, and dosages of utilized immune cells. Quality of all involved trials was evaluated based on Cochrane Handbook. ${ }^{26}$

\section{Outcome definition}

Clinical responses include treatment efficacy, prognosis, and immune function. Treatment efficacy was assessed in terms of the complete response (CR) rates, near CR (nCR), partial response (PR) rates, minuteness response (MR), stable disease (SD) rates, progressive disease (PD) rates, nonresponse $(\mathrm{NR})$ rate, overall response rate (ORR) $(\mathrm{ORR}=\mathrm{CR}+\mathrm{nCR}+\mathrm{PR})$, and disease control rate $(\mathrm{DCR})(\mathrm{DCR}=\mathrm{CR}+\mathrm{nCR}+\mathrm{PR}+\mathrm{SD})$. Patients' quality of life (QoL) was evaluated using performance status (Ps) score and Karnofsky performance score (Kps). Prognosis was analyzed based on the following indicators: tumor cells' percentage, serum levels of $\beta 2$-microglobin ( $\beta 2-\mathrm{M}), \mathrm{M}$ protein, $24 \mathrm{~h}$ urine light chains, and serum creatinine (Scr). The immune function of MM patients before and after treatment was evaluated by lymphocyte subsets $\left(\mathrm{CD}^{+}, \mathrm{CD}^{+}, \mathrm{CD}^{+} /\right.$ $\mathrm{CD}^{+}$, and $\mathrm{CD}^{+} \mathrm{CD} 25^{+}$) and cytokines' secretion (silverstaining nucleolar organizer region $[\mathrm{AgNOR}], \mathrm{IFN}-\gamma, \mathrm{IL}-2$, IL-4, IL-6, IL-10, IL-12, and TGF- $\beta$ ).

\section{Statistical analysis}

The analysis was performed using Review Manager 5.2 (Cochrane Collaboration). $P<0.05$ indicated statistical significance. Heterogeneity among studies was assessed by Cochran's $Q$ test to determine the most suitable analysis model, ${ }^{27}$ and funnel plots were used to assess the publication bias of the involved studies. $I^{2}<50 \%$ or $P>0.1$ indicated that the studies were homogenous. Odds ratio (OR) was the principal measurement for therapeutic effects and was presented with a $95 \%$ confidence interval (CI). Sensitivity analysis was conducted to evaluate the consistency of the results and the influence of single study on overall risk estimate.

\section{Results}

\section{Search results}

A total of 2,953 articles were identified upon initial retrieve. After title and abstract review, 2,899 articles were excluded because they did not include clinical trials $(n=2,683)$, were duplication or repetition $(n=182)$, or unrelated studies $(n=34)$, leaving 54 studies as potentially relevant. After detailed assessment of full texts, articles with insufficient

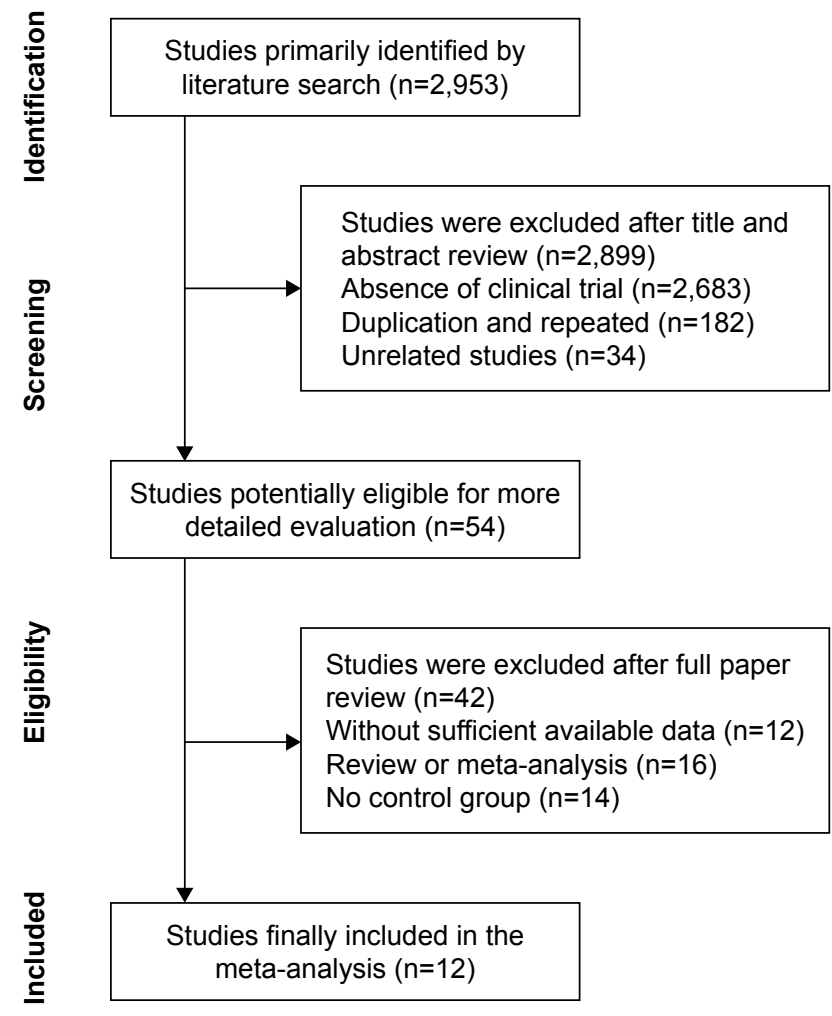

Figure I Flow diagram of the selection process.

data $(n=12)$ or without control group $(n=14)$, and reviews or meta-analyses $(n=16)$ were excluded. Finally, 12 trials involving $594 \mathrm{MM}$ patients were included in this metaanalysis (Figure 1).

\section{Patient characteristics}

After selection, all 12 trials that met our inclusion criteria were conducted in China. In total, $300 \mathrm{MM}$ patients were treated by DC-CIK in combination with chemotherapy, while 294 patients were treated by chemotherapy alone. Detailed information of the involved trials and patients is presented in Table 2. DC and CIK were obtained from autologous peripheral blood and cultured in vitro for amplification. Most patients received intravenous transfusion for more than three time over $1 \times 10^{10} \mathrm{DC}-\mathrm{CIK}$ each cycle (Table 1 ).

\section{Quality assessment}

The assessment of bias risk is shown in Figure S1. Five studies were determined as low risk, two studies were not truly randomized controlled trials and the remaining five studies lacked clear description of randomization process. All included trials did not provide clear description of allocation, performance, and detection risks. The attrition risks of involved trials were low; four trials were considered as unclear risk owing to 
Table 2 Clinical information from the eligible trials in the meta-analysis

\begin{tabular}{|c|c|c|c|c|c|c|}
\hline \multirow{2}{*}{$\begin{array}{l}\text { Included } \\
\text { studies }\end{array}$} & \multirow[t]{2}{*}{ Nation } & \multirow{2}{*}{$\begin{array}{l}\text { D-S } \\
\text { stage }\end{array}$} & \multirow{2}{*}{$\begin{array}{l}\text { Patients, } \\
\text { Con/Exp }\end{array}$} & \multicolumn{2}{|l|}{ Age (years) } & \multirow[t]{2}{*}{ Parameter types } \\
\hline & & & & Con & Exp & \\
\hline Ding $(2013)^{14}$ & China & II-III & $16 / 14$ & $71.3 \pm 4.0$ (mean) & $70.5 \pm 3.4$ (mean) & ORR \\
\hline Gao $(2015)^{15}$ & China & III & $60 / 60$ & $48.2 \pm 3.4$ (mean) & $47.8 \pm 3.6$ (mean) & ORR, DCR, cytokines, Kps \\
\hline Lu $(2015)^{16}$ & China & I-III (ISS) & $12 / 10$ & 60 (median) & 6I (median) & Treg, ORR, DCR \\
\hline Sun $(2012)^{17}$ & China & II-III & $24 / 24$ & $58.2 \pm 15.4$ (mean) & $59.8 \pm 17.8$ (mean) & $\begin{array}{l}\text { ORR, DCR, TC, } \beta 2-M, M, \text { ULC, Scr, AgNOR, } \\
\text { cytokines }\end{array}$ \\
\hline $\operatorname{Tan}(2016)^{18}$ & China & ND & $30 / 30$ & $58.6 \pm 8.8$ (mean) & $59.6 \pm 9.2$ (mean) & LYM subsets, ORR, cytokines, ADE \\
\hline Wang $(2015)^{19}$ & China & II-III & $14 / 15$ & $61.4 \pm 3.5$ (mean) & $60.7 \pm 4.0$ (mean) & ORR, DCR \\
\hline Yan $(2014)^{20}$ & China & ND & $18 / 22$ & ND & ND & ORR, DCR, TC, $\beta 2-M$, Scr \\
\hline Ye $(2016)^{21}$ & China & ND & $16 / 17$ & ND & ND & ORR \\
\hline $\mathrm{Yu}(2016)^{22}$ & China & I-III & $30 / 30$ & $57.6 \pm 5.3$ (mean) & $59.3 \pm 4.3$ (mean) & LYM subsets, ORR, DCR \\
\hline Zhao $(2015)^{23}$ & China & I-III (ISS) & $24 / 26$ & $56.3 \pm 10.6$ (mean) & $57.1 \pm 11.8$ (mean) & LYM subsets, cytokines, TC, $\beta 2-M, M$, ULC, Scr, Ps \\
\hline Zhao $(2016)^{24}$ & China & I-III (ISS) & $20 / 22$ & $56.5 \pm 12.7$ (mean) & $57.6 \pm 13.5$ (mean) & Treg, TC, $\beta 2-M, M$, ULC, Scr, Ps \\
\hline Zhong $(2012)^{25}$ & China & I-III (ISS) & $30 / 30$ & $58.2 \pm 15.4$ (mean) & $61.8 \pm 17.8$ (mean) & ORR, DCR, TC, $\beta 2-M$, ULC, Scr, Ps \\
\hline
\end{tabular}

Notes: Con, control group (chemotherapy alone group); Exp, experimental group (chemotherapy plus DC-CIK immunotherapy); $M$, serum level of $M$ protein; $\beta 2-M$, serum level of $\beta 2$-microglobin; ULC, $24 \mathrm{~h}$ urine light chain content.

Abbreviations: ADE, adverse events; AgNOR, silver-staining nucleolar organizer region; DC-CIK, dendritic cells and cytokine-induced killer cells; DCR, disease control rate; D-S, Durie-Salmon; ISS, International Staging System; Kps, Karnofsky performance score; LYM, lymphocyte; ND, nondetermined; ORR, overall response rate; Ps, performance status; Scr, serum creatinine; TC, tumor cell.

selective reporting, and the other two studies were considered as high risk for missing primary outcome data.

\section{Therapeutic efficacy assessments}

As shown in Figures $2 \mathrm{~A}$ and $\underline{\mathrm{S} 2}$ and Table 3, the pooled analysis showed that patients who underwent combined therapy had significantly improved CR, PR, ORR, and DCR (CR: OR $=2.71, \mathrm{CI}=1.60-4.58, P=0.0002$; PR: $\mathrm{OR}=1.49$, $\mathrm{CI}=1.01-2.20, P=0.04$; ORR: $\mathrm{OR}=2.77, \mathrm{CI}=1.88-4.10$, $P<0.00001$; DCR: $\mathrm{OR}=2.90, \mathrm{CI}=1.72-4.90, P<0.0001)$ and significantly decreased $\mathrm{PD}$ and $\mathrm{NR}$ ( $\mathrm{PD}$ : $\mathrm{OR}=0.34$, $\mathrm{CI}=0.20-0.58, P<0.0001 ; \mathrm{NR}: \mathrm{OR}=0.24, \mathrm{CI}=0.07-0.80$, $P=0.02$ ), whereas the $\mathrm{nCR}, \mathrm{MR}$, and SD did not show significant difference from patients who received chemotherapy alone (nCR: $\mathrm{OR}=1.35, \mathrm{CI}=0.58-3.11, P=0.48$; MR: OR $=0.91, \mathrm{CI}=0.52-1.57, P=0.73$; SD: $\mathrm{OR}=0.66$, $\mathrm{CI}=0.35-1.25, P=0.21)$. Fixed-effect models were used to analyze OR rate because of low heterogeneity. Funnel plots of ORR and DCR showed no substantial publication bias in our analysis (Figure 2B and C).

\section{Prognosis evaluation}

As shown in Figure 3, the analysis confirmed that the percentage of tumor cells and the levels of $\beta 2-\mathrm{M}, \mathrm{M}$ protein, $24 \mathrm{~h}$ urine light chains, and Scr were significantly decreased after combined treatment (percentage of tumor cells: $\mathrm{OR}=-35.15, \mathrm{CI}=-43.58$ to $-26.71, P<0.00001 ; \beta 2-\mathrm{M}$ : $\mathrm{OR}=-13.80, \mathrm{CI}=-17.49$ to $-10.10, P<0.00001$; $\mathrm{M}$ protein: $\mathrm{OR}=-17.77, \mathrm{CI}=-21.68$ to $-13.87, P<0.00001$; urinary light chain: $\mathrm{OR}=-11.39, \mathrm{CI}=-13.00$ to -9.78 , $P<0.00001$; Scr: OR $=-215.79, \mathrm{CI}=-246.51$ to -185.06 , $P<0.00001)$. Compared to patients treated by chemotherapy alone, those who received combined therapy showed better prognosis (Figure $\mathrm{S} 3$, percentage of tumor cells: $\mathrm{OR}=-7.15$, $\mathrm{CI}=-13.92$ to $-0.38, P=0.04 ; \beta 2-\mathrm{M}: \mathrm{OR}=-4.59, \mathrm{CI}=-6.88$ to $-2.29, P<0.0001 ; \mathrm{M}$ protein: $\mathrm{OR}=-9.55, \mathrm{CI}=-12.61$ to $-6.49, P<0.00001$; urinary light chain: $\mathrm{OR}=-4.95$, $\mathrm{CI}=-6.20$ to $-3.69, P=0.006$; $\mathrm{Scr}: \mathrm{OR}=-58.52, \mathrm{CI}=-85.30$ to $-31.72, P<0.0001)$. No significant publication bias was found (Figure 4), and the random effects model was applied for significant heterogeneity.

\section{QoL assessment}

QoL was evaluated in this analysis. Result showed that patients' QoL was significantly improved, indicated by Ps and Kps after treatment (Figure 5, Ps: $\mathrm{OR}=-1.27, \mathrm{CI}=-1.83$ to $-0.71, P<0.00001$; Kps: $\mathrm{OR}=28.90, \mathrm{CI}=27.51-30.29$, $P<0.00001)$. QoL of patients in the combined group was more superior with statistical significance than that of the control group (Figure S4, Ps: OR $=-0.44, \mathrm{CI}=-0.60$ to -0.28 , $P<0.00001$; Kps: $\mathrm{OR}=6.00, \mathrm{CI}=4.52-7.48, P<0.00001$ ).

\section{Immune function evaluation}

The immune status of MM patients was examined before and after treatment. The percentages of $\mathrm{CD}^{+}$cells and $\mathrm{CD} 4^{+} / \mathrm{CD} 8^{+}$ratio were significantly increased after DC-CIK treatment (Figure $\mathrm{S} 5$ and Table 4, $\mathrm{CD}^{+}$: $\mathrm{OR}=3.14$, $\mathrm{CI}=1.65-4.64, P<0.0001 ; \mathrm{CD}^{+} / \mathrm{CD}^{+}: \mathrm{OR}=0.38$, 
A

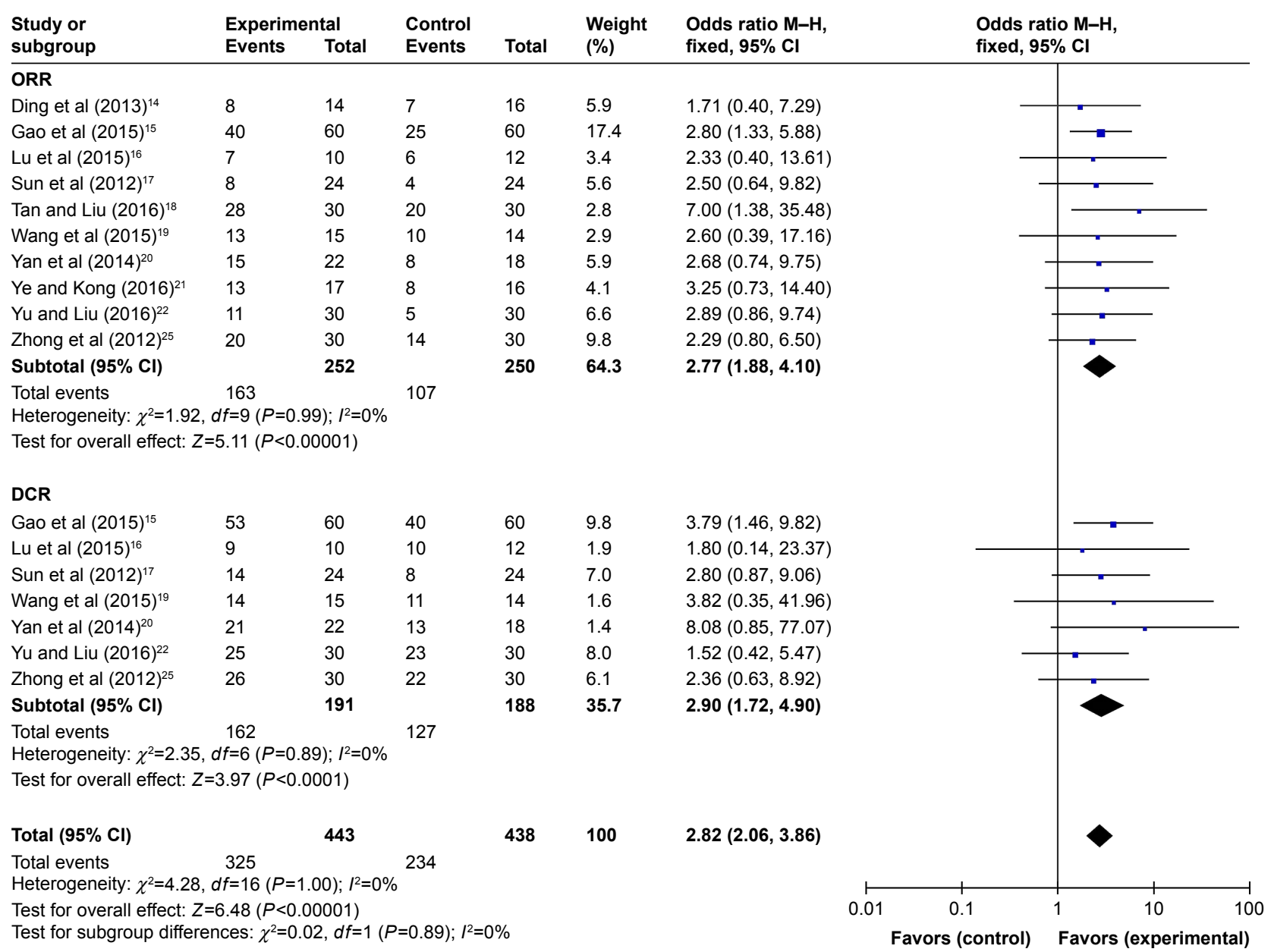
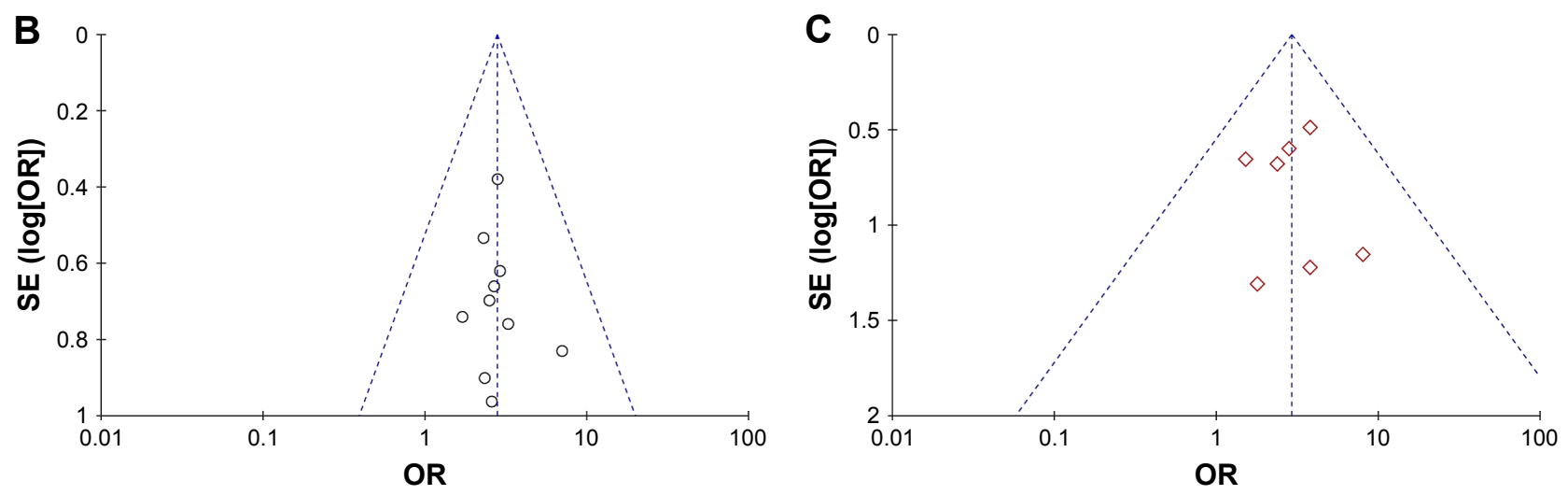

Figure 2 (A) Forest plot of the comparison of ORR and DCR between the experimental and control groups. (B) Funnel plot of ORR. (C) Funnel plot of DCR. Control group, chemotherapy alone group; experimental group, chemotherapy plus DC-CIK immunotherapy. The fixed-effects meta-analysis model (Mantel-Haenszel method) was used. Abbreviations: $\mathrm{Cl}$, confidence interval; DC-CIK, dendritic cells and cytokine-induced killer cells; DCR, disease control rate; IV, inverse variance; M-H, Mantel-Haenszel test; OR, odds ratio; ORR, overall response rate; SE, standard error.

$\mathrm{CI}=0.18-0.59, P=0.0002)$, whereas proportions of $\mathrm{CD}^{+}$ and $\mathrm{CD} 4{ }^{+} \mathrm{CD} 25^{+}$were significantly decreased (Figure $\mathrm{S} 5$ and Table 4, $\mathrm{CD}^{+}$: $\mathrm{OR}=-9.26, \mathrm{CI}=-11.58$ to -6.95 , $P<0.00001 ; \mathrm{CD}^{+}{ }^{+} \mathrm{CD} 25^{+}: \mathrm{OR}=-2.97, \mathrm{CI}=-4.44$ to -1.50 , $P<0.0001)$. Levels of AgNOR, IFN- $\gamma$, IL-2, and IL-12 were significantly increased after DC-CIK therapy (Figure S6 and Table 5, AgNOR: $\mathrm{OR}=1.05, \mathrm{CI}=0.40-1.70, P=0.002$; IFN- $\gamma$ : OR $=33.91, \mathrm{CI}=30.68-37.14, P<0.00001$; IL-2: $\mathrm{OR}=19.56, \mathrm{CI}=9.74-29.39, P<0.0001$; IL-12: $\mathrm{OR}=12.25$, $\mathrm{CI}=1.53-22.97, P=0.03$ ), whereas levels of IL-4, IL-6, IL-10, 
Table 3 Comparison of CR, nCR, PR, MR, SD, PD, NR, ORR, and DCR between the experimental and control groups

\begin{tabular}{|c|c|c|c|c|c|c|c|c|}
\hline \multirow[t]{2}{*}{ Parameter } & \multicolumn{2}{|c|}{ Number of patients $(n)$} & \multirow{2}{*}{$\begin{array}{l}\text { Analysis } \\
\text { method }\end{array}$} & \multicolumn{2}{|c|}{ Heterogeneity } & \multirow[t]{2}{*}{ OR } & \multirow[t]{2}{*}{$95 \% \mathrm{Cl}$} & \multirow[t]{2}{*}{$P$-value } \\
\hline & Experimental group & Control group & & $I^{2}(\%)$ & $P$-value & & & \\
\hline CR & 252 & 250 & Fixed & 0 & 0.98 & $2.7 I$ & $1.60-4.58$ & 0.0002 \\
\hline $\mathrm{nCR}$ & 105 & 102 & Fixed & 0 & 0.88 & 1.35 & $0.58-3.11$ & 0.48 \\
\hline PR & 252 & 250 & Fixed & 0 & 1.00 & 1.49 & $1.0 \mathrm{I}-2.20$ & 0.04 \\
\hline$M R$ & 162 & 160 & Fixed & 0 & 0.79 & 0.91 & $0.52-1.57$ & 0.73 \\
\hline SD & 100 & 102 & Fixed & 0 & 0.58 & 0.66 & $0.35-1.25$ & 0.21 \\
\hline PD & 191 & 188 & Fixed & 0 & 0.89 & 0.34 & $0.20-0.58$ & $<0.000 \mathrm{I}$ \\
\hline NR & 47 & 46 & Fixed & 15 & 0.28 & 0.24 & $0.07-0.80$ & 0.02 \\
\hline ORR & 252 & 250 & Fixed & 0 & 0.99 & 2.77 & $1.88-4.10$ & $<0.0000$ I \\
\hline DCR & 191 & 188 & Fixed & 0 & 0.89 & 2.90 & I.72-4.90 & $<0.0001$ \\
\hline
\end{tabular}

Abbreviations: $\mathrm{Cl}$, confidence interval; $\mathrm{CR}$, complete response; $\mathrm{DCR}$, disease control rate; $\mathrm{MR}$, minuteness response; $\mathrm{nCR}$, near $\mathrm{CR}$; NR, nonresponse; OR, odds ratio; ORR, overall response rate; PD, progressive disease; PR, partial response; SD, stable disease.

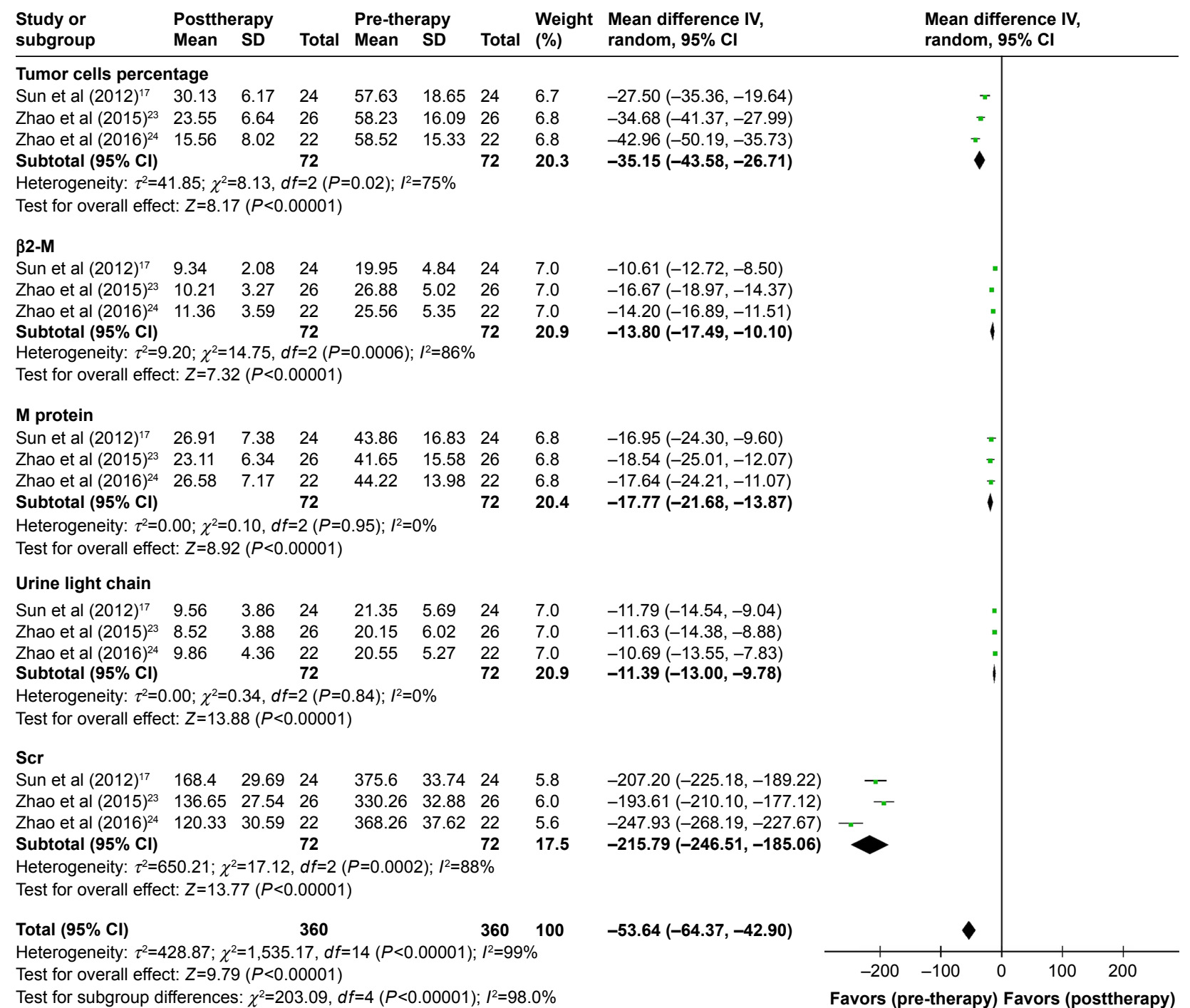

Figure 3 Forest plot of the comparison of percentage of tumor cells, serum level of $\beta 2-M$, serum level of M protein, $24 \mathrm{~h}$ urine light chain content, and Scr level between the experimental and control groups. Control group, chemotherapy alone group; experimental group, chemotherapy plus DC-CIK immunotherapy. The random effects meta-analysis model (inverse variance method) was used.

Abbreviations: $\mathrm{Cl}$, confidence interval; DC-CIK, dendritic cells and cytokine-induced killer cells; $\beta 2-\mathrm{M}$, $\beta 2$-microglobin; IV, inverse variance; Scr, serum creatinine. 

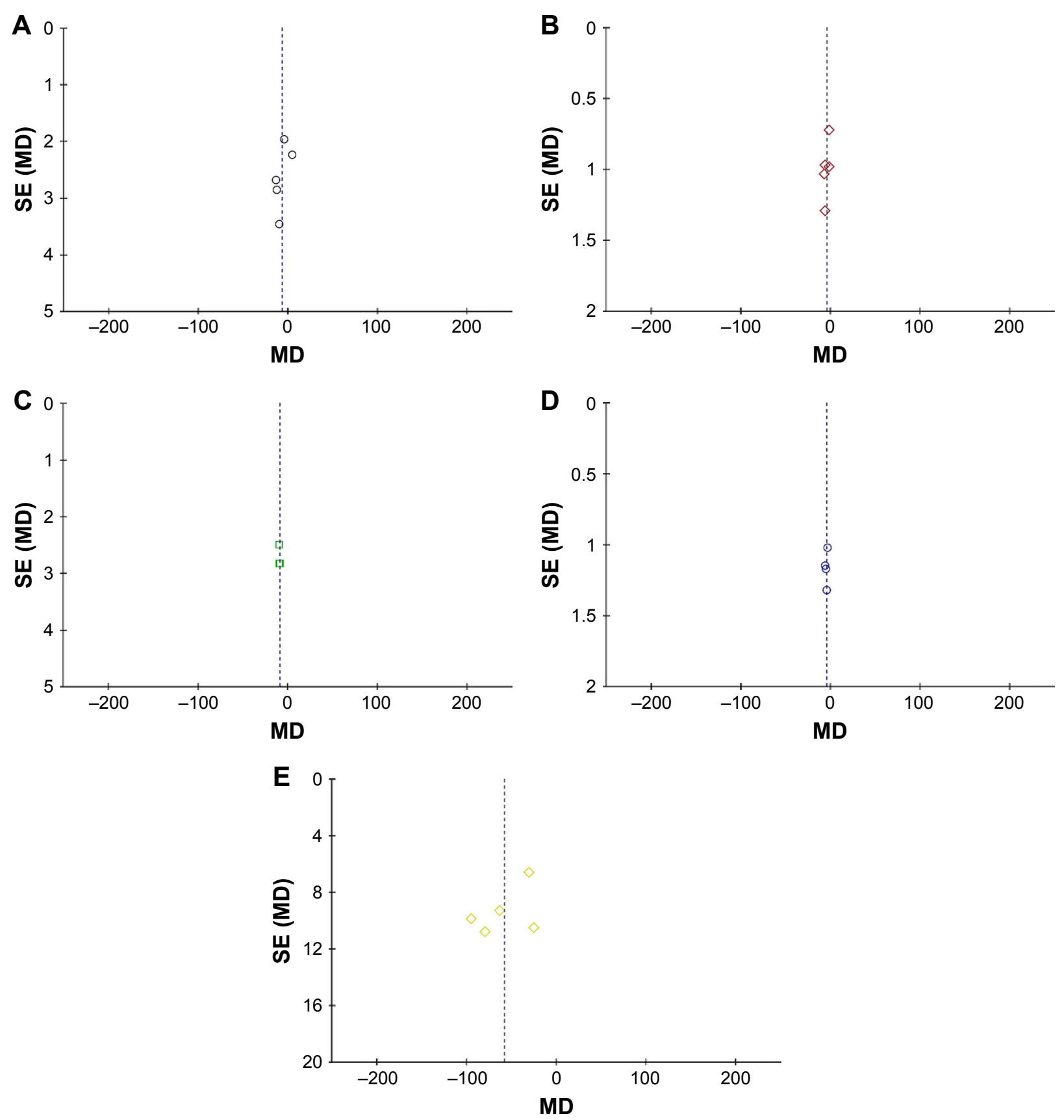

Figure 4 Funnel plot of percentage of tumor cells (A), serum level of $\beta 2-M(B)$, serum level of M protein (C), 24 h urine light chain content (D), and Scr level (E). Abbreviations: $\beta 2-M$, $\beta 2$-microglobin; MD, mean difference; Scr, serum creatinine; SE, standard error.

and TGF- $\beta$ were significantly decreased (Figure S6 and Table 5, IL-4: OR $=-8.34, \mathrm{CI}=-10.06$ to $-6.62, P<0.00001$; IL-6: $\mathrm{OR}=-35.01, \mathrm{CI}=-59.02$ to $-11.00, P=0.004$; IL-10: $\mathrm{OR}=-11.10, \mathrm{CI}=-13.13$ to $-9.07, P<0.00001$; TGF- $\beta$ : $\mathrm{OR}=-0.35, \mathrm{CI}=-0.58$ to $-0.13, P=0.002$ ).

\section{Adverse events assessment}

Safety of DC-CIK therapy was evaluated in this metaanalysis. The most common side effects include chills and fever, which subsided naturally within $24 \mathrm{~h}$ without any medical treatment. No serious adverse events or death was reported after DC-CIK therapy (Table 6). However, incidence of side effects in the experimental and control groups was not compared in most included trials. As shown in Figure S7, adverse events including nausea and vomiting, palpitation and chest tightness, myocardial enzyme increased, aminotransferase increased, and gastrointestinal adverse reaction were compared in Tan et al's ${ }^{18}$ and Yu et al's ${ }^{22}$ studies 
A

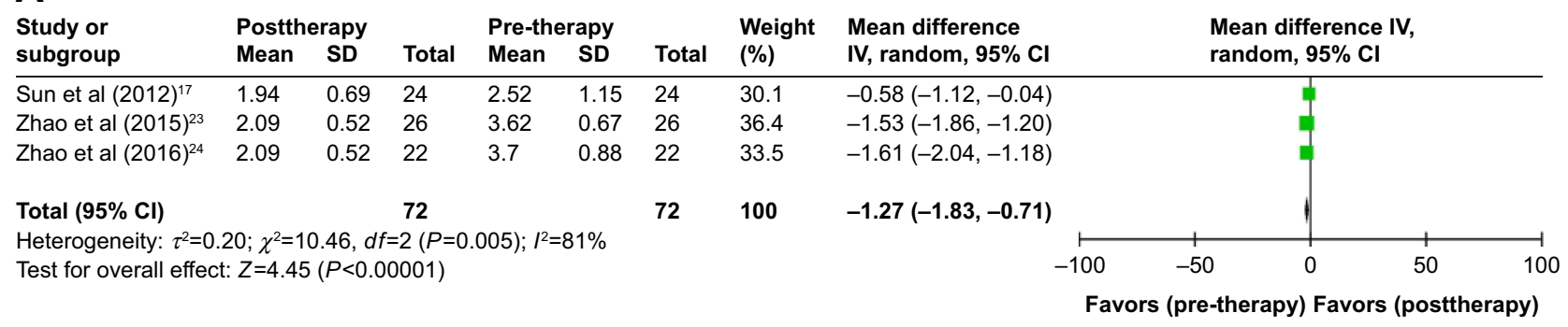

\section{B}

\begin{tabular}{|c|c|c|c|c|c|c|c|c|c|c|c|c|}
\hline \multirow{2}{*}{$\begin{array}{l}\text { Study or } \\
\text { subgroup } \\
\text { Gao et al }(2015)^{15}\end{array}$} & \multicolumn{2}{|c|}{$\begin{array}{l}\text { Posttherapy } \\
\text { Mean SD }\end{array}$} & \multirow{2}{*}{$\frac{\text { Total }}{60}$} & \multicolumn{2}{|c|}{$\begin{array}{l}\text { Pre-therapy } \\
\text { Mean SD }\end{array}$} & \multirow{2}{*}{$\begin{array}{l}\text { Total } \\
60\end{array}$} & \multirow{2}{*}{$\begin{array}{l}\text { Weight } \\
\text { (\%) } \\
100\end{array}$} & $\begin{array}{l}\text { Mean difference } \\
\text { IV, fixed, } 95 \% \mathrm{CI}\end{array}$ & \multicolumn{3}{|c|}{$\begin{array}{l}\text { Mean difference IV, } \\
\text { fixed, } 95 \% \mathrm{CI}\end{array}$} & \\
\hline & 91.02 & 4.26 & & 62.12 & 3.48 & & & $28.90(27.51,30.29)$ & & & & \\
\hline Total $(95 \% \mathrm{Cl})$ & & & 60 & & & 60 & 100 & $28.90(27.51,30.29)$ & & & & \\
\hline \multicolumn{6}{|c|}{ Heterogeneity: not applicable } & & & & & & & \\
\hline \multicolumn{6}{|c|}{ Test for overall effect: $Z=40.70(P<0.00001)$} & & & -100 & -50 & 0 & 50 & 100 \\
\hline
\end{tabular}

Figure 5 Forest plot of the comparison of Ps (A) score and Kps (B) in pre- and posttherapy.

Abbreviations: $\mathrm{Cl}$, confidence interval; IV, inverse variance; Kps, Karnofsky performance score; Ps, performance status.

and the result showed no significant difference between the two groups (nausea and vomit: $\mathrm{OR}=0.56, \mathrm{CI}=0.12-2.57$, $P=0.45$; palpitation and chest tightness: $\mathrm{OR}=0.73$, $\mathrm{CI}=0.16-3.46, P=0.70$; myocardial enzyme increased: $\mathrm{OR}=1.38, \mathrm{CI}=0.28-6.80, P=0.69$; aminotransferase increased: $\mathrm{OR}=1.00, \mathrm{CI}=0.13-7.60, P=1.00$; gastrointestinal adverse reaction: $\mathrm{OR}=2.07, \mathrm{CI}=0.18-24.15, P=0.56)$.

\section{Sensitivity analysis}

Sensitivity analysis was conducted, and two trials ${ }^{14,18}$ were excluded because DC was not applied to patients. Moreover, by eliminating two low-quality trials, ${ }^{20,21}$ the stability of primary endpoints (ORR and DCR) was numerically verified (Table 7). The results of this analysis were consistent with our overall analysis of the pooled trials.

\section{Discussion}

DC-CIK immunotherapy has been considered as a promising option to treat malignancies due to its unique biological characteristics. ${ }^{28-31}$ DC-CIK kill tumor cells through FasLand perforin-mediated pathways upon direct contact and secretion of cytokines such as IL-2, TNF- $\alpha$, and IFN- $\gamma{ }^{11,29}$ Furthermore, CIK lyse cancer cells in an MHC-unrestricted manner through activating NK cell receptors such as DNAX accessory molecule-1, NKp46, NKG2D, and NKp30. ${ }^{28,30,31}$ In recent years, several studies reported that DC-CIK immunotherapy is a safe and feasible treatment option for MM patients. $^{23,25}$ However, the diverse clinical protocols may lead to different therapeutic effects and immune responses. In this study, we investigated a great number of clinical trials to achieve a high statistical reliability.

Our meta-analysis revealed that patients who received adjuvant immunotherapy of DC-CIK combined with chemotherapy presented a more favorable efficacy and prognosis compared to MM patients who received chemotherapy alone. Compared to patients treated by chemotherapy alone, patients treated with combined therapy showed markedly increased ORR $(P<0.00001)$ and DCR $(P<0.0001)$. As the main evaluation for curative effects and prognosis, percentage of tumor cells and levels of $\beta 2-\mathrm{M}, \mathrm{M}$ protein, $24 \mathrm{~h}$ urine light chains, and Scr also showed promising results in combined therapy. ${ }^{32-36}$ Patients' QoL was also significantly improved after combined

Table 4 Comparison of lymphocyte subsets before and after DC-CIK therapy

\begin{tabular}{|c|c|c|c|c|c|c|c|c|}
\hline \multirow[t]{2}{*}{ Parameter } & \multicolumn{2}{|l|}{ DC-CIK } & \multirow{2}{*}{$\begin{array}{l}\text { Analysis } \\
\text { method }\end{array}$} & \multicolumn{2}{|c|}{ Heterogeneity } & \multirow[t]{2}{*}{ OR } & \multirow[t]{2}{*}{$95 \% \mathrm{Cl}$} & \multirow[t]{2}{*}{$P$-value } \\
\hline & After treatment (n) & Before treatment (n) & & $I^{2}(\%)$ & $P$-value & & & \\
\hline $\mathrm{CD}^{+}$ & 86 & 86 & Fixed & 43 & 0.17 & 3.14 & 1.65 to 4.64 & $<0.0001$ \\
\hline $\mathrm{CD}^{+}$ & 86 & 86 & Fixed & 55 & 0.11 & -9.26 & -11.58 to -6.95 & $<0.00001$ \\
\hline $\mathrm{CD}^{+} / \mathrm{CD}^{+}$ & 86 & 86 & Fixed & 72 & 0.03 & 0.38 & 0.18 to 0.59 & 0.0002 \\
\hline $\mathrm{CD}^{+}{ }^{+} \mathrm{CD} 25^{+}$ & 88 & 88 & Fixed & 80 & 0.002 & -2.97 & -4.44 to -1.50 & $<0.0001$ \\
\hline
\end{tabular}

Abbreviations: $\mathrm{Cl}$, confidence interval; DC-CIK, dendritic cells and cytokine-induced killer cells; OR, odds ratio. 
Table 5 Comparison of cytokines before and after DC-CIK therapy

\begin{tabular}{|c|c|c|c|c|c|c|c|c|}
\hline \multirow[t]{2}{*}{ Parameter } & \multirow{2}{*}{$\frac{\text { CIK/DC-CIK }}{\text { After treatment (n) }}$} & \multirow{2}{*}{$\frac{\text { CIK/DC-CIK }}{\text { Before treatment }(n)}$} & \multirow{2}{*}{$\begin{array}{l}\text { Analysis } \\
\text { method }\end{array}$} & \multicolumn{2}{|c|}{ Heterogeneity } & \multirow[t]{2}{*}{ OR } & \multirow[t]{2}{*}{$95 \% \mathrm{Cl}$} & \multirow[t]{2}{*}{$P$-value } \\
\hline & & & & $I^{2}(\%)$ & $P$-value & & & \\
\hline AgNOR & 50 & 50 & Random & 67 & 0.08 & 1.05 & 0.40 to 1.70 & 0.002 \\
\hline IFN- $\gamma$ & 26 & 26 & Random & & & 33.91 & 30.68 to 37.14 & $<0.0000$ I \\
\hline IL-2 & 86 & 86 & Random & 97 & $<0.00001$ & 19.56 & 9.74 to 29.39 & $<0.0001$ \\
\hline IL-4 & 26 & 26 & Random & & & -8.34 & -10.06 to -6.62 & $<0.0000$ I \\
\hline IL-6 & 30 & 30 & Random & & & -35.01 & -59.02 to -11.00 & 0.004 \\
\hline IL-10 & 26 & 26 & Random & & & -11.10 & -13.13 to -9.07 & $<0.0000$ I \\
\hline IL-12 & 24 & 24 & Random & & & 12.25 & 1.53 to 22.97 & 0.03 \\
\hline TGF- $\beta$ & 56 & 56 & Random & 0 & 0.34 & -0.35 & -0.58 to -0.13 & 0.002 \\
\hline
\end{tabular}

Abbreviations: AgNOR, silver-staining nucleolar organizer region; $\mathrm{Cl}$, confidence interval; CIK, cytokine-induced killer cells; DC-CIK, dendritic cells and CIK; OR, odds ratio.

therapy $(P<0.00001)$. These results indicated that DC-CIK immunotherapy lowered the tumor load possibly through killing tumor cells, by which patients' life quality improved.

Immune reconstitution is important for treating malignancies, and the immunosuppressed status of cancer patients has been reported previously. ${ }^{8,37}$ The exercise of immune function depends on a proper $\mathrm{CD} 4^{+} / \mathrm{CD}^{+}$ratio. Moreover, $\mathrm{CD} 4{ }^{+} \mathrm{CD} 25^{+}$regulatory $\mathrm{T}$ cells negatively regulated the anti-tumor activity of DC-CIK immune cells. ${ }^{38}$ Our analysis showed significantly increased percentages of $\mathrm{CD} 4^{+}$cells and $\mathrm{CD}^{+} / \mathrm{CD}^{+}$ratio and significantly decreased percentages of $\mathrm{CD}^{+}$cells and $\mathrm{CD} 4^{+} \mathrm{CD} 25^{+}$cells upon $\mathrm{DC}-\mathrm{CIK}$ immunotherapy $(P<0.00001)$. AgNOR is an indicator of rDNA transcriptional activity in the nucleus. T-lymphocyte AgNOR content further reflects the $\mathrm{T}$ lymphocyte and extended cellular immune function status..$^{39}$ In our analysis, AgNOR was significantly increased after DC-CIK treatment. All these results indicated that the immune function of MM patients was improved upon DC-CIK immunotherapy.
The balance between Th1 and Th2 cells is crucial in DC-CIK immunotherapy. Th1 cytokines, including IFN- $\gamma$, IL-2, and IL-12, enhance the cytotoxicity of DC-CIK, whereas Th2 cytokines, such as IL-4, IL-6, IL-10, and TGF- $\beta$, are associated with tumor immune escape. ${ }^{11,12}$ Our analysis showed that DC-CIK immunotherapy was associated with increased IFN- $\gamma$, IL- 2 , and IL-12 $(P<0.01)$ whereas it decreased IL-4, IL-6, IL-10, and TGF- $\beta(P<0.01)$, indicating an important role of Th1/Th2 cytokines in DC-CIK immunotherapy.

Safety is the top priority of the clinical treatment, and it is also key factor for the development of DC-CIK immunotherapy's clinical application. Our analysis showed that DC-CIK was safe for MM therapy. Chills and fever were the most common side effects during DC-CIK therapy but were well tolerated, and no serious adverse events or death occurred during therapy.

There are some limitations in our analysis. First of all, the number of MM patients included in this study is not big enough and the follow-up time was short. Apart from that, the

Table 6 Information of adverse effects during the therapy

\begin{tabular}{|c|c|c|}
\hline Included studies & Control group & Experimental group (events/total) \\
\hline Ding et al $(2013)^{14}$ & $\begin{array}{l}\text { Fatigue }(7 / 16) \text {, thrombocytopenia }(6 / 16) \text {, peripheral } \\
\text { neuropathy }(I I, 5 / 16)\end{array}$ & Fever $(2 / / 4)$ \\
\hline Gao et al $(2015)^{15}$ & ND & ND \\
\hline Lu et al $(2015)^{16}$ & ND & Chills, fever, and skin itching (2/l0) \\
\hline Sun et al $(2012)^{17}$ & Dizziness, constipation, fatigue, nausea, rash & Chills and fever $(2 / 24)$ \\
\hline Tan and Liu $(2016)^{18}$ & $\begin{array}{l}\text { Nausea and vomit }(5 / 30) \text {, palpitation and chest tightness } \\
(3 / 30) \text {, myocardial enzyme increased }(3 / 30) \text {, amin- } \\
\text { otransferase increased }(2 / 30) \text {, creatinine increased }(4 / 30)\end{array}$ & $\begin{array}{l}\text { Nausea and vomit }(3 / 30) \text {, palpitation and chest tightness } \\
(2 / 30) \text {, myocardial enzyme increased }(4 / 30) \text {, amin- } \\
\text { otransferase increased }(2 / 30) \text {, creatinine increased }(3 / 30)\end{array}$ \\
\hline Wang et al $(2015)^{19}$ & Herpes zoster virus infection $(3 / 14)$ & Chills and fever $(1 / 15)$ \\
\hline Yan et al $(20 \mid 4)^{20}$ & ND & ND \\
\hline Ye and Kong $(2016)^{21}$ & ND & ND \\
\hline Yu and Liu $(2016)^{22}$ & Gastrointestinal reaction (I/30), palpitation (I/30) & $\begin{array}{l}\text { Gastrointestinal reaction }(2 / 30) \text {, myocardial enzyme } \\
\text { increased }(1 / 30) \text {, palpitation }(1 / 30)\end{array}$ \\
\hline Zhao et al $(2015)^{23}$ & Nerve terminal injury $(5 / 24)$ & Chills and fever $(2 / 26)$ \\
\hline Zhao et al $(2016)^{24}$ & Nerve terminal injury $(5 / 20)$ & Chills and fever $(2 / 22)$ \\
\hline Zhong et al $(2012)^{25}$ & ND & Chills and fever $(4 / 30)$ \\
\hline
\end{tabular}

Abbreviation: ND, nondetermined. 
Table 7 Outcomes of sensitivity analysis

\begin{tabular}{|c|c|c|c|c|c|c|c|c|}
\hline \multirow[t]{2}{*}{ Parameter } & \multirow{2}{*}{$\begin{array}{l}\text { Number of patients }(n) \\
\text { Exp group }\end{array}$} & \multirow{2}{*}{$\frac{\text { Number of patients }(\mathrm{n})}{\text { Con group }}$} & \multirow{2}{*}{$\begin{array}{l}\text { Analysis } \\
\text { method }\end{array}$} & \multicolumn{2}{|c|}{ Heterogeneity } & \multirow[t]{2}{*}{ OR } & \multirow[t]{2}{*}{$95 \% \mathrm{Cl}$} & \multirow[t]{2}{*}{$P$-value } \\
\hline & & & & $I^{2}(\%)$ & $P$-value & & & \\
\hline \multicolumn{9}{|l|}{ ORR } \\
\hline With low quality & 252 & 250 & Fixed & 0 & 0.99 & 2.77 & $1.88-4.10$ & $<0.0000$ I \\
\hline Without low quality & 213 & 216 & Fixed & 0 & 0.97 & 2.75 & I.79-4.2| & $<0.00001$ \\
\hline With CIK therapy & 252 & 250 & Fixed & 0 & 0.99 & 2.77 & $1.88-4.10$ & $<0.00001$ \\
\hline Without CIK therapy & 208 & 204 & Fixed & 0 & 1.00 & 2.67 & I.75-4.08 & $<0.0000 \mathrm{I}$ \\
\hline \multicolumn{9}{|l|}{ DCR } \\
\hline With low quality & 191 & 188 & Fixed & 0 & 0.89 & 2.90 & $1.72-4.90$ & $<0.0001$ \\
\hline Without low quality & 169 & 170 & Fixed & 0 & 0.92 & 2.70 & I.57-4.64 & 0.0003 \\
\hline
\end{tabular}

Notes: Con, control group (chemotherapy alone group); Exp, experimental group (chemotherapy plus DC-CIK immunotherapy).

Abbreviations: $\mathrm{Cl}$, confidence interval; CIK, cytokine-induced killer cells; DC-CIK, dendritic cells and CIK; DCR, disease control rate; OR, odds ratio; ORR, overall response rate.

12 trials included in this meta-analysis were conducted based on Chinese population. Although the effectiveness of DCCIK immunotherapy on hematopoietic malignancies has been widely reported, ${ }^{40-46}$ its usage on MM is still rare outside of China. One American trial was included firstly upon literature retrieve, but it was then excluded because of insufficient data. ${ }^{44}$ There are three registered ongoing clinical trials in which MMs are treated by DC-CIK immunotherapy accompanied with conventional regimens, among which two are registered in the USA (NCT00477035 and NCT00185757) and one in Singapore (NCT00460694). Up to now, no paper based on these trials and meeting our inclusion criteria has been published. We will keep paying close attention to global studies in our later studies. Finally, the selection of chemotherapy regimen is also important for the determination of optimal therapeutic strategy. However, based on currently available literatures, there are insufficient data to perform a statistical analysis to compare different combination therapies. We will keep following up with upcoming clinical trials to obtain relevant data when available.

\section{Conclusion}

Our study verified the therapeutic effects and safety of adjuvant DC-CIK immunotherapy in combination with chemotherapy for MM patients. DC-CIK immunotherapy enhances the treatment efficacy of chemotherapy remarkably and improves prognosis of MM patients by reconstructing the immune system. Therefore, adjuvant immunotherapy of DC-CIK combined with chemotherapy is a promising treatment option for MM patients.

\section{Author contributions}

All authors contributed toward data analysis, drafting and critically revising the paper and agree to be accountable for all aspects of the work.

\section{Disclosure}

The authors report no conflicts of interest in this work.

\section{References}

1. Zhang T, Wang S, Lin T, et al. Systematic review and meta-analysis of the efficacy and safety of novel monoclonal antibodies for treatment of relapsed/refractory multiple myeloma. Oncotarget. 2017;8(20): 34001-34017.

2. Jung SH, Lee HJ, Vo MC, Kim HJ, Lee JJ. Immunotherapy for the treatment of multiple myeloma. Crit Rev Oncol Hematol. 2017;111: 87-93.

3. Al-Hujaily EM, Oldham RA, Hari P, Medin JA. Development of novel immunotherapies for multiple myeloma. Int J Mol Sci. 2016; 17(9):E1506.

4. Nooka AK, Kastritis E, Dimopoulos MA, Lonial S. Treatment options for relapsed and refractory multiple myeloma. Blood. 2015;125(20): 3085-3099.

5. Aguiar PM, de Mendonca Lima T, Colleoni GWB, Storpirtis S. Efficacy and safety of bortezomib, thalidomide, and lenalidomide in multiple myeloma: an overview of systematic reviews with meta-analyses. Crit Rev Oncol Hematol. 2017;113:195-212.

6. Ludwig H, Avet-Loiseau H, Blade J, et al. European perspective on multiple myeloma treatment strategies: update following recent congresses. Oncologist. 2012;17(5):592-606.

7. Sonneveld P, De Wit E, Moreau P. How have evolutions in strategies for the treatment of relapsed/refractory multiple myeloma translated into improved outcomes for patients? Crit Rev Oncol Hematol. 2017; 112:153-170.

8. Zhou C, Liu D, Li J, et al. Chemotherapy plus dendritic cells co-cultured with cytokine-induced killer cells versus chemotherapy alone to treat advanced non-small-cell lung cancer: a meta-analysis. Oncotarget. 2016;7(52):86500-86510.

9. Mu Y, Wang WH, Xie JP, Zhang YX, Yang YP, Zhou CH. Efficacy and safety of cord blood-derived dendritic cells plus cytokine-induced killer cells combined with chemotherapy in the treatment of patients with advanced gastric cancer: a randomized phase II study. Onco Targets Ther. 2016;9:4617-4627.

10. Olioso P, Giancola R, Di Riti M, Contento A, Accorsi P, Iacone A. Immunotherapy with cytokine induced killer cells in solid and hematopoietic tumours: a pilot clinical trial. Hematol Oncol. 2009; 27(3):130-139.

11. Mu Y, Zhou CH, Chen SF, et al. Effectiveness and safety of chemotherapy combined with cytokine-induced killer cell/dendritic cellcytokine-induced killer cell therapy for treatment of gastric cancer in China: a systematic review and meta-analysis. Cytotherapy. 2016;18(9): 1162-1177. 
12. Zhang L, Mu Y, Zhang A, et al. Cytokine-induced killer cells/dendritic cells-cytokine induced killer cells immunotherapy combined with chemotherapy for treatment of colorectal cancer in China: a metaanalysis of 29 trials involving 2,610 patients. Oncotarget. 2017;8(28): 45164-45177.

13. Liu Y, Mu Y, Zhang A, et al. Cytokine-induced killer cells/dendritic cells and cytokine-induced killer cells immunotherapy for the treatment of esophageal cancer in China: a meta-analysis. Onco Targets Ther. 2017; 10:1897-1908.

14. Ding L, Zhu JP, Shao LZ, Xu M. Clinical observation of CIK cells comined with VD regimen in treatment of refractory and recurrent multiple myeloma of the aged people. Chin Med Biotechnol. 2013; 8(6):429-432.

15. Gao ZX, Tong ZH, Zhang Z, Li Z. The impact of efficacy and the levels of VEGF, IL-2 and TNF-a of chemotherapy combined immune therapy (DC-CIK) treatment of multiple myeloma. J Hunan Normal Univ. 2015;12(3):47-49.

16. Lu G, Xing J, Liu GQ, et al. Clinical efficacy of DC and CIK immunotherapy combined with chemotherapy and its impact on Treg cells in newly diagnosed multiple myeloma. J Exp Hematol. 2015;23(3): 737-741.

17. Sun Y, Kuang H, Zhang XY, et al. Retrospective study of adoptive immunotherapy (autologous DC-CIK) combined with thalidomide on patients with relapsed or refractory multiple myeloma. Immunol J. 2012;28:324-328

18. Tan SF, Liu L. Effect and safety of CIK cell infusion on peripheral blood immune cell level in the elderly patients with multiple myeloma. $J$ Exp Hematol. 2016;24(2):482-486.

19. Wang L, Xu L, Liu GQ, Xu M, Xing J, Ding HF. Clinical observation of DC-CIK combined with bortezomib in treatment patient of multiple myeloma. Med J Chin People Health. 2015;27(1):1-3.

20. Yan Y, Ruan LH, Yang HP. Clinical efficacy of autologous antigen sensitized biological immunotherapy combined with chemotherapy in the treatment of multiple myeloma. Chin Prac Med. 2014;9(24) $151-152$.

21. Ye R, Kong XM. Efficacy observation and nursing care of 17 cases bone pain caused by multiple myeloma after treated with DC-CIK cells. J Qilu Nurs. 2016;22(23):76-77.

22. Yu Q, Liu QH. Effect of immunotherapy combined with chemotherapy on peripheral blood T, B lymphocyte, and regulatory $\mathrm{T}$ cell levels in patients with multiple myeloma. J Clin Res. 2016;88(6):1086-1092.

23. Zhao X, Ji CY, Liu GQ, et al. Immunomodulatory effect of DC/CIK combined with chemotherapy in multiple myeloma and the clinical efficacy. Int J Clin Exp Pathol. 2015;8(10):13146-13155.

24. Zhao X, Ding HF, Xu M, et al. Clinical efficacy of dendritic cells and cytokine-induced killer cells combined with chemotherapy for treating newly diagnosed multiple myeloma and their effect on function of CD4(+) CD25(+) T cells in peripheral blood. J Exp Hematol. 2016; 24(1):122-126.

25. Zhong GC, Yan B, Sun Y, et al. Clinical efficacy of immunotherapy of dendritic cell and cytokine-induced killer cell combined with chemotherapy for treatment of multiple myeloma. Chin J Hematol. 2012; 33(12):1000-1003.

26. Zeng X, Zhang Y, Kwong JS, et al. The methodological quality assessment tools for preclinical and clinical studies, systematic review and meta-analysis, and clinical practice guideline: a systematic review. J Evid Based Med. 2015;8(1):2-10.

27. Jackson D, White IR, Riley RD. Quantifying the impact of betweenstudy heterogeneity in multivariate meta-analyses. Stat Med. 2012; 31(29):3805-3820.

28. Gao X, Mi Y, Guo N, et al. Cytokine-induced killer cells as pharmacological tools for cancer immunotherapy. Front Immunol. 2017;8:774.

29. Lee HK, Kim YG, Kim JS, et al. Cytokine-induced killer cells interact with tumor lysate-pulsed dendritic cells via CCR5 signaling. Cancer Lett. 2016;378(2):142-149.
30. Lu X, Zhu A, Cai X, et al. Role of NKG2D in cytokine-induced killer cells against multiple myeloma cells. Cancer Biol Ther. 2012;13(8): 623-629.

31. Marten A, Renoth S, von Lilienfeld-Toal M, et al. Enhanced lytic activity of cytokine-induced killer cells against multiple myeloma cells after co-culture with idiotype-pulsed dendritic cells. Haematologica. 2001;86(10):1029-1037.

32. Bettini R, Redaelli S, Maino C, et al. [Prognostic value of serum beta2-microglobulin in multiple myeloma]. Recenti Prog Med. 2005; 96(2):81-86. Italian.

33. Tao ZF, Fu WJ, Yuan ZG, Wang DX, Chen YB, Hou J. Prognostic factors and staging systems of multiple myeloma. Chin Med J (Engl). 2007;120(19):1655-1658

34. Kyrtsonis MC, Vassilakopoulos TP, Kafasi N, et al. Prognostic value of serum free light chain ratio at diagnosis in multiple myeloma. Br J Haematol. 2007;137(3):240-243.

35. Takamatsu Y, Muta T. [Clinical courses and risk factors for progression of smoldering multiple myeloma: a nationwide cohort study in Japan] Rinsho Ketsueki. 2015;56(8):1005-1010. Japanese.

36. Sekiguchi N, Takezako N, Haga M, Nagata A, Noto S, Miwa A. [Significance of bortezomib and dexamethasone therapy for multiple myeloma showing a serum creatinine level above $2 \mathrm{mg} / \mathrm{dl}]$. Rinsho Ketsueki. 2011;52(2):87-89. Japanese.

37. Lee JH, Lim YS, Yeon JE, et al. Adjuvant immunotherapy with autologous cytokine-induced killer cells for hepatocellular carcinoma Gastroenterology. 2015;148(7):1383-1391.e6.

38. Liu H, Li J, Wang F, et al. Comparative study of different procedures for the separation of peripheral blood mononuclear cells in cytokineinduced killer cell immunotherapy for hepatocarcinoma. Tumour Biol. 2015;36(4):2299-2307.

39. Ruschoff J, Neumann K, Contractor H, Plate K, Thomas C. Assessment of nucleolar organizer regions by automatic image analysis in breast cancer: correlation with DNA content, proliferation rate, receptor status and histopathological grading. J Cancer Res Clin Oncol. 1990;116(5) 480-485.

40. Linn YC, Niam M, Chu S, et al. The anti-tumour activity of allogeneic cytokine-induced killer cells in patients who relapse after allogeneic transplant for haematological malignancies. Bone Marrow Transplant. 2012;47(7):957-966.

41. Leemhuis T, Wells S, Scheffold C, Edinger M, Negrin RS. A phase I trial of autologous cytokine-induced killer cells for the treatment of relapsed Hodgkin disease and non-Hodgkin lymphoma. Biol Blood Marrow Transplant. 2005;11(3):181-187.

42. Schmidt-Wolf IG, Finke S, Trojaneck B, et al. Phase I clinical study applying autologous immunological effector cells transfected with the interleukin-2 gene in patients with metastatic renal cancer, colorectal cancer and lymphoma. Br J Cancer. 1999;81(6):1009-1016.

43. Linn YC, Yong HX, Niam M, et al. A phase I/II clinical trial of autologous cytokine-induced killer cells as adjuvant immunotherapy for acute and chronic myeloid leukemia in clinical remission. Cytotherapy. 2012;14(7):851-859.

44. Laport GG, Sheehan K, Baker J, et al. Adoptive immunotherapy with cytokine-induced killer cells for patients with relapsed hematologic malignancies after allogeneic hematopoietic cell transplantation. Biol Blood Marrow Transplant. 2011;17(11):1679-1687.

45. Introna M, Pievani A, Borleri G, et al. Feasibility and safety of adoptive immunotherapy with CIK cells after cord blood transplantation. Biol Blood Marrow Transplant. 2010;16(11):1603-1607.

46. Introna M, Borleri $\mathrm{G}$, Conti $\mathrm{E}$, et al. Repeated infusions of donorderived cytokine-induced killer cells in patients relapsing after allogeneic stem cell transplantation: a phase I study. Haematologica. 2007; 92(7):952-959. 


\section{Publish your work in this journal}

Drug Design, Development and Therapy is an international, peerreviewed open-access journal that spans the spectrum of drug design and development through to clinical applications. Clinical outcomes, patient safety, and programs for the development and effective, safe, and sustained use of medicines are the features of the journal, which

has also been accepted for indexing on PubMed Central. The manuscript management system is completely online and includes a very quick and fair peer-review system, which is all easy to use. Visit http://www.dovepress.com/testimonials.php to read real quotes from published authors.

Submit your manuscript here: http://www.dovepress.com/drug-design-development-and-therapy-journal 